\title{
THE EFFECTS OF SUMMARIZING USING INFOGRAPHICS ON EFL LEARNERS' READING COMPREHENSION.
}

\author{
1Dyah Supraba L, ${ }^{2}$ Rini Silvana \\ 12 English Education Study Program Teachers Training and Education Faculty \\ Muhammadiyah University of Tangerang \\ 2 MAN 2 Tangerang
}

\begin{abstract}
The purpose of this paper is to describe EFL learners' experiences while using infographics in a reading class. The pedagogical intervention, based on the use of infographic application (Canva) as an alternative tool to help them summarize reading passages, was implemented to enhance their reading comprehension. The data were gathered from teacher's journal, questionnaires and the results of students' reading comprehension tests. The findings revealed that the students viewed the use of infographics could motivate and enabled them to summarize the assigned reading topics much easier. In addition, the assignments incorporating the use of infographic application encouraged them to participate actively in English reading activities in a collaborative atmosphere, allow them to develop their creativity and raise positive attitudes toward the role of technological tools in educational settings.
\end{abstract}

\section{Keywords: English reading, infographics, reading comprehension}

\section{INTRODUCTION}

For decades, research and practice in English teaching has identified the "four skills" listening, speaking, reading and writing - as of paramount importance (Brown, 2007). As one of the core communication skills, reading plays an important role in helping learners to obtain knowledge and information available from written sources. Furthermore, reading skills support learners to acquire other language skills (listening, speaking and writing). Brown (2007) has suggested interactive and integrated approaches to language teaching which emphasize the interrelatiohsip of skills. In addition, Anderson (2003) stated that it is essential to equipped EFL learners with reading skills, as it helps learners not only to master English but also to make progress and other development in other areas of learning. That is why in any EFL environment we will find reading comprehension assessment, as it is also included in English subject for high schools in Indonesia. And eventually, high school students will find reading comprehension questions on their final exam.

Teaching reading comprehension in EFL classrooms indeed can be challenging. Suryanto (2017) had compiled some studies about English reading comprehension problems in Indonesian cultural contexts. Teachers have encountered situations where students feel bored in reading class. Boring materials discourage students' interest in doing classroom reading activities. Thus, teachers have to struggle to activate students' learning and ensuring their understanding toward the contents of the lesson. It is also commonly found that students are lack of reading strategies. To be effective readers, Mistar, Zuhairi, and Yanti 
Globish (An English-Indonesian journal for English, Education and Culture)

Vol. 9 No.2 July 2020

P-ISSN: 2301-9913, E-ISSN: 2597-9132

DOI: http://dx.doi.org/10.31000/globish.v7i2

(2016) suggested that students should be equipped with more reading strategies like predicting, text mapping, and summarizing.

Those problems had happened in one of the grade 12 classes, MAN 1 Tangerang. Teacher found out that the students looked bored in English reading class. As she conversed with her students, she learned that they were not interested because the contexts of the reading materials were not familiar to them. Nevertheless they were able to do the reading comprehension tasks, as those tasks were quite easy and not challenging enough for them. Still, the teacher was not really sure that students comprehended the reading text completely. She wanted to find out an effective strategy to improve her students' reading comprehension so that the knowledge they got could stay longer in their cognition.

Nowadays, EFL teachers also realize the importance of inserting $21^{\text {st }}$ century skills in learning activities. Dating back nearly two decades, policy makers and educators have agreed to prepare young generation with the essential $21^{\text {st }}$ century skills. It is believed that teachers should introduce these skills to their students so that they will be ready to shape the future themselves. The P21 forum has recommended the learning skills and competencies that are called as Four Cs of $21^{\text {st }}$ Century learning, which are: collaboration; communication; critical thinking and creativity (Santosa, et.al 2019). Thus, researcher would also try a pedagogical intervention that could facilitate these $4 \mathrm{Cs}$ in our reading comprehension setting.

Based on those challenges, researchers would like to find out whether there could be any strategy or tools that could make students more interested in reading class. The researcher also intended to improve students' reading skills by giving more engaging reading comprehension tasks and finding strategies that could make the knowledge from reading passage stay longer. In addition, teacher would also like to facilitate her students to develop their 4 Cs. Therefore, strategy that would be used in our research to improve students' reading comprehension our research was summarizing. Furthermore, the researchers would like to try out the strategy by implementing Infographic Aplication Canva to raise students' interests and develop their 4 Cs.

\subsection{Problem Statements}

(1) Reading class should be more interesting and motivating for students

(2) Reading class should facilitate students develop 4 Cs skills.

(3) Teachers needed to find more effective reading strategy to improve their reading comprehension. 
Globish (An English-Indonesian journal for English, Education and Culture)

Vol. 9 No.2 July 2020

P-ISSN: 2301-9913, E-ISSN: 2597-9132

DOI: http://dx.doi.org/10.31000/globish.v7i2

\subsection{Research Questions}

(1) Can using Infographic for summary writing raise students' interest in Reading Class?

(2) Can using Infographic for summary writing develop students' core skills?

(3) Can using Infographic for summary writing improve students' Reading Comprehension?

\section{THEORETICAL FRAMEWORK}

\subsection{Reading Comprehension}

Reading is an interaction between reader and text. Anderson (2003) had defined that reading is a fluent process of readers combining information from a text and their own background knowledge to build meaning. The goal of reading is comprehension. The text, the reader, fluency and strategies combined together define the act of reading (Figure 1).

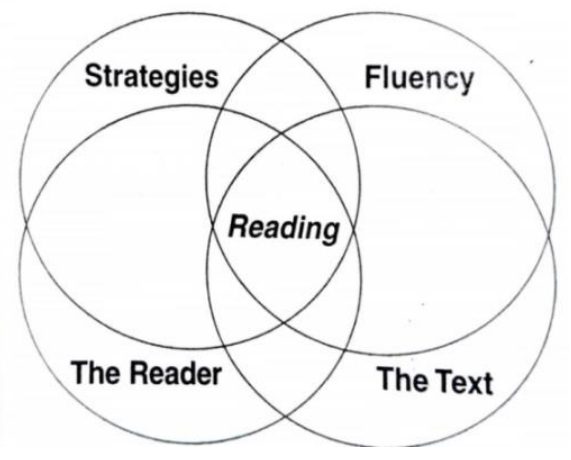

FIGURE 1. Definition of Reading (Anderson, 2003)

Readers need process to comprehend a text. Reading process can be divided into three category: bottom-up models; top-down models and interactive models (Anderson, 2003). Bottom-up models start with the fundamental basics of letter and sound recognition, building up to identification of grammatical structures, sentences and longer text so that eventually learners achieve comprehension. Top-down models begin with the idea that comprehension resides in the reader. The reader uses background knowledge, makes prediction and search the text to confirm or reject the predictions that are made. Interactive models combine elements of both bottom-up and top-down models, where a reader can comprehend a text by synthesizing information from several 
Globish (An English-Indonesian journal for English, Education and Culture)

Vol. 9 No.2 July 2020

P-ISSN: 2301-9913, E-ISSN: 2597-9132

DOI: http://dx.doi.org/10.31000/globish.v7i2

knowledge sources simultaneously. An EFL learner can comprehend a reading text well by integrating both bottom-up and top-down processes efficiently.

In teaching reading comprehension, teachers often get students to read intensively in class. Intensive reading means students will look at a short reading text and do various exercise on it. According to Harmer (2012) intensive reading is often used to train students in different reading skills, skimming and scanning. Skimming is a reading skill to get the general meaning or main idea from a text. Scanning is a reading skill to find the specific or more detailed information.

Incorporating the reading strategies should be incorporated in teaching reading to assist students to be successful readers (Anderson, 2003). Akkakoson (2012) mentioned that teachers need to improve students' performance in reading comprehension because effective reading strategies can assist readers to develop better reading achievement. Similarly, Fitrisia, Tan and Yusuf(2015) also had reported that reading strategies play an important role for students to strengthen their performance in reading comprehension. To be effective readers, students should be capable of employing some reading strategies like predicting, text mapping, and summarizing (Mistar, Zuhairi, \& Yanti, 2016).

\subsection{Summarizing}

Summarizing is a task done by reader to produce synopsis or overview a reading text to show the learning experience that the readers has been thru in the reading process. As stated by Brown and Abbeywickrama (2010), summarizing requires a synopsis or overview of the text that express the main idea and supporting details accurately. It facilitates learner to use the vocabularies they have learned, to show their ability to organize information in logical order, and maximize the use of the language to clearly express their ideas. According to Lee and Van Pattern (2004), summarizing shows what the students have had in their reading experience on information. By summarizing, the readers can internalize the content of the reading, thereby ensuring that they are reading to learn.

\subsection{Teaching Generation $\mathrm{Z}$}

The students that became our subjects in this study were part the Generation Z, as they were born in 2002 or 2003.Generation Z learners were born and raised surrounded by rich technology environment. Wilson and Jan (2003), as cited by Santosa in (2017), these learners shall practice inquiry-based learning so that they can perceive 
Globish (An English-Indonesian journal for English, Education and Culture)

Vol. 9 No.2 July 2020

P-ISSN: 2301-9913, E-ISSN: 2597-9132

DOI: http://dx.doi.org/10.31000/globish.v7i2

issues from multiple perspectives, analyze them and construct new knowledge to understand the issues. Teaching and learning process should be directed to a critical perspective rather than receptive one only.

Before teaching them, educators need to learn the characteristic of Generation Z (Sparks and Honey, 2014). Generation Z learners are technology savvy. They use gadget $\mathrm{n}$ internet to search information. They communicate in speed. They like communicate using symbol and image. Their social circles are global. They also like to create and cocreate. Although they are multitasking, these learners have short attention span. In order to make learning process more enjoyable for learners, teachers need to know how to connect to gen Z. Sparks and Honey (2014) suggested teachers to raise students' interest and facilitate their curiosity by attracting them with technology. Teachers shall communicate with them often and treat them as adults. We need to collaborate with them and facilitate them to collaborate with their peers. Let them be and become creative. And we must be tactful about their short attention span.

\subsection{Teaching $4 C s$ in EFL context}

Education is not only about providing knowledge for young generation, but also preparing them with skills that can make them successful in their future individual and social life. In order to prepare these young generation, Partnership for $21^{\text {st }}$ century skills (2007) has suggested frameworkfor 21st Century Learning. This P21 forum stated stated that to prepare students for more complex life and work environments in the 21st century, they shall be equipped with learning and innovation skills. A focus on creativity, critical thinking, communication and collaboration is essential to prepare students for the future.

Halvorsen (2018) gave some recommendations for promoting the 4Cs in English language classroom. Learners can develop and practice their critical thinking by analyzing issues and solving problems. All four language skills can easily be activated when students are asked to research a topic, discuss or debate that topic with peers, and write about what they find. To develop creativity in students, teachers need to facilitate students with different learning styles to be creative and give students choices whenever possible to express their ideas and opinions. The next two Cs are collaboration and communication. Many of the things that language teachers are already doing in the classroom, like pair and group work, peer review, and projectbased learning (PBL), are excellent to support the development of collaboration and communication. Digital literacy skills and interactions outside the classroom become 
Globish (An English-Indonesian journal for English, Education and Culture)

Vol. 9 No.2 July 2020

P-ISSN: 2301-9913, E-ISSN: 2597-9132

DOI: http://dx.doi.org/10.31000/globish.v7i2

essential elements to support language learning. Some language programs are exploring online or blended learning experiences, where some of the instruction and interaction may take place through computers or smartphones. Although, students who are "digital natives" can learn language from online games or social media, they will need to find and critically analyze information online, create and edit video or audio projects. These skills and many others need to be taught and actively practiced in the classroom.

\subsection{Implementation of Infographics in EFL Learning.}

The term infographics comes from information and graphics, which means data visualization which illustrate information and statistic that is created to become a visual narrative. As stated by Matrix and Hodson (2014) an infographic, otherwise known as a data visualization, is created using graphic design software, and uses pie charts, icons, decorative fonts, diagrams to illustrate information and statistics - creating a visual narrative. Similar to a traditional research essay, an infographic assignment challenges students to visually communicate a thesis, supported by citations and statistics sourced from the scholarly literature and the popular press. Rather than present this position in a text-based format, students must design an information visualization to illustrate their argument, using computer software or using online design tools to semi-automate the process.
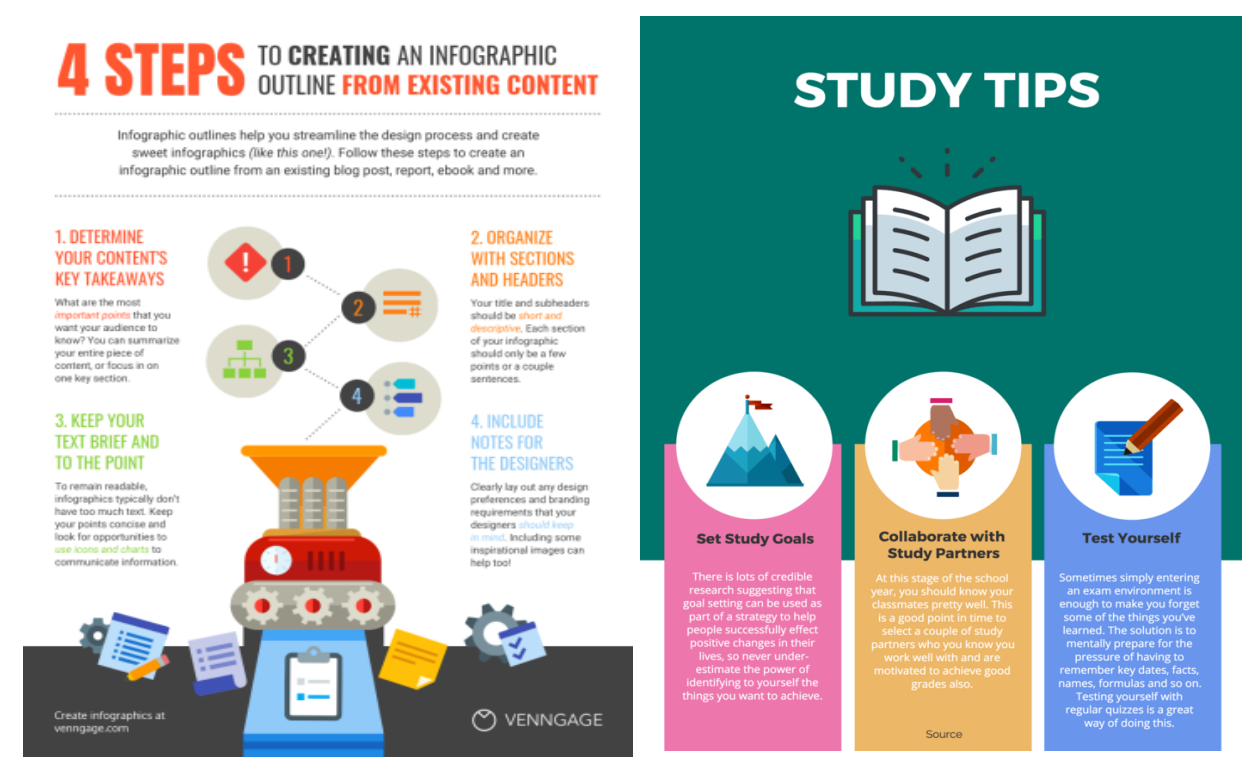

Figure 2. Examples of Infographic Products. 
Globish (An English-Indonesian journal for English, Education and Culture)

Vol. 9 No.2 July 2020

P-ISSN: 2301-9913, E-ISSN: 2597-9132

DOI: http://dx.doi.org/10.31000/globish.v7i2

However, integration of visual aids and similar strategies were rarely found in reading comprehension research studies. One of few was a study conducted by Manowong (2017). The research showed that infographic assignments could make learning English easier and motivate EFL students to read English texts in an enjoyable way. The students identified the benefits of using technological tools, which provide a learning environment that made learning convenient, engaging, and fun. Furthermore, Online tools such as Google Docs, Canva, and Padlet had made them to conduct various levels of thinking and skills, enabled the promotion of critical and creative thinking as well as collaborative skills.

Kongwat and Sukavatee (2019) made use of infographics as visual aids to foster students' reading comprehension. Their research was designed to explore the effects of collaborative reading strategy using infographics on students' reading comprehension, while not only developing students' comprehension, but also encouraging students to be more engaged in the lesson. They concluded that integration of infographics and collaborative reading instruction in the classroom can enhance 21st century teaching and learning. Applying collaborative reading instruction using infographics in the classroom in a way that suits students' learning styles and preferences could enhance their reading comprehension.

Figure 3. Comparisson between Infographic and Essay

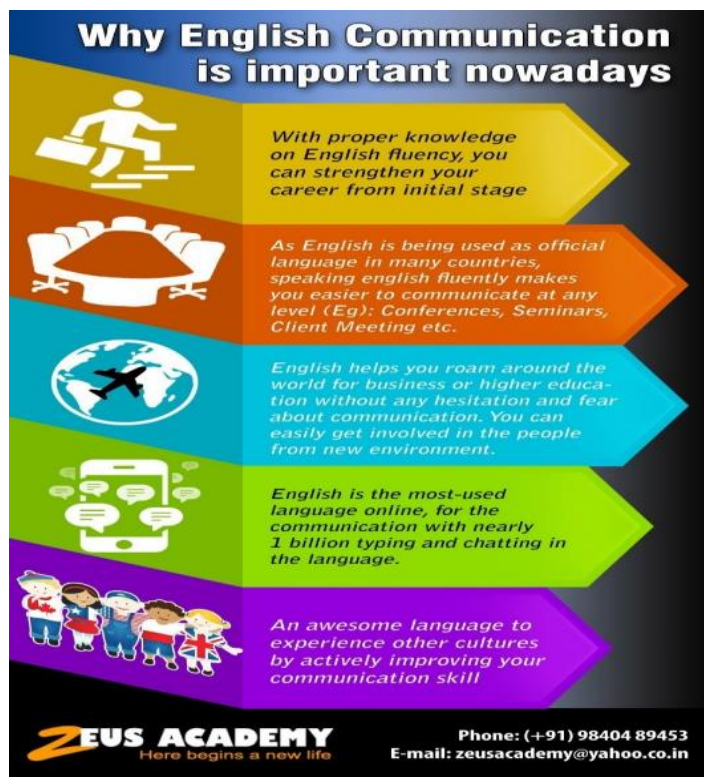

Why is Learning English Important?

Language is the mean of communication. Mostly groups of society have their own languages. Some of them appear the top global languages. Most people in the world hear about English, Arabic, and Mandarin. However English is the most global spoken language. Then if a man wants to catch a global goal, he has to master English.

Everyone recognize that English is an international language. English is used in writing and speaking by many people all over the world. It can be either as a first or second language. We even hear British, American, Australian, and even Singaporean English. Those various names of English are used as the first language in those countries. Furthermore, some countries have their own languages as a mother language but also use English mostly in daily communication

Besides usage in daily interaction, English is also used as a key to open doors leading to scientific and technical knowledge. No wonder we find manual guides and instructions of many devices written in English. Even if we have a pack of instant noodle, we will see the cooking instruction also written in English. This transfer of science and technical will include many countries in economic, social and politics development.

Finally, the most easily seen in the importance of learning English is that most top requirement in filling job opportunities is the ability using English; active or passive. Job applicants who master English are more favorable than ones who do not.

The above facts prove that everybody needs to learn English if he likes to greet the global era.

\section{METOHODOLOGY}

\subsection{Subject, place and time of research}


Globish (An English-Indonesian journal for English, Education and Culture)

Vol. 9 No.2 July 2020

P-ISSN: 2301-9913, E-ISSN: 2597-9132

DOI: http://dx.doi.org/10.31000/globish.v7i2

The subjects of this research were 40 students of grade 11 . There were 24 females and 17 males. It took place in MAN 1 Tangerang. The research was conducted from August 5 to September 23, 2019; two hours session per week on every Wednesdays.
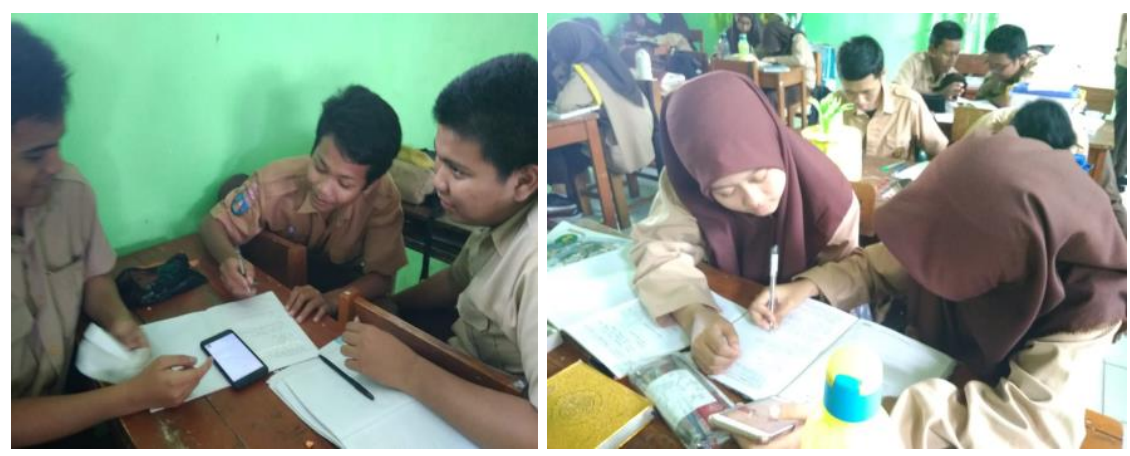

Figure 3. English Reading Class, Grade 12 MAN 1 Tangerang

\subsection{The Classroom Action Research Methods}

The classroom action research was conducted to investigate how using Canva improved summary writing in two cycles. According to Kemmis and Taggart (1988) as cited in Burns (2010), there are four phases in each cycle of Classroom Action Research: planning, observing and acting, and reflecting.

The planning part which was also the first stage of the cycle was the preparation part. Here, the teaching schedule, lesson plans, the material from the units for the activity and questionnaire were prepared.

The second stage consisted of the acting part and the observing part. These two parts of the cycle were conducted simultaneously. The acting part was the teaching learning part in the classroom based on a prepared lesson plan where the students used Canva Application for summary writing. Then, next is the observing part. The observing part was the result part. In this part, the observer noted the result of her observation concerning the improvement of learners' summary writing through the implementation of using Canva and learning process in the classroom.

The reflecting part was the evaluation part. It was where the significance of the research outcomes were measured and analyzed. Here, it was decided whether a second cycle would be essential to the research for the first one is not sufficient. 
Globish (An English-Indonesian journal for English, Education and Culture)

Vol. 9 No.2 July 2020

P-ISSN: 2301-9913, E-ISSN: 2597-9132

DOI: http://dx.doi.org/10.31000/globish.v7i2

Cycle 1 of this research was conducted in August 2020. It consisted three learning sessions, and another session is for test and reflection. Cycle 2 was conducted in September 2020. It consisted of three learning sessions and one session for final test.

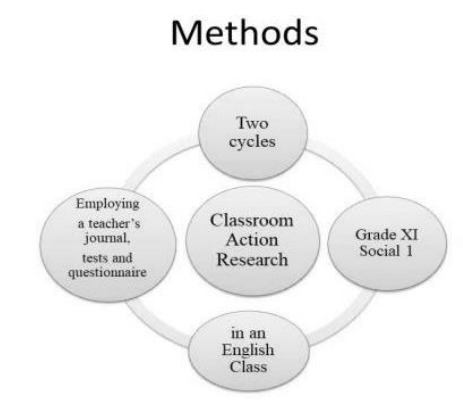

Figure 4. The summary of Research Methodology

\subsection{Research Procedures}

- Preparation:

(1) Researcher compiled and analyzed students' summary writing products from previous learning sessions.

(2) Researcher prepared lesson plan teaching material and teaching aid that would be used in Canva app intervention. She set objective of the lesson and made the lesson plan, prepare the teaching materials, teaching aids and research instruments.

(3) Researcher explained to students about how to use infographic. She gave them example of summary writing using Canva. Next, she asked the students to download the app. Students were able to learn and explore the app independently.

- Implementation:

The pedagogic interventions were taken in 2 cycles. Each intervention contained pre-reading, whilst reading and post reading.

- Observation

During the intervention, researcher observed students' reading comprehension by assessing their summary writing products posted on instagram.

- Reflection 
Globish (An English-Indonesian journal for English, Education and Culture)

Vol. 9 No.2 July 2020

P-ISSN: 2301-9913, E-ISSN: 2597-9132

DOI: http://dx.doi.org/10.31000/globish.v7i2

Reflection on the whole process would include data interpretation from observation, the results of students' reading comprehension tests, teacher's journal for each cycle and questionnaires.

\subsection{Data Collection Techniques and Instrument}

The data collection were acquired from students summary writing products, infographic posts on instagram, teacher journal and questionnaires

\subsection{Data Analysis}

This research mostly were analyzed qualitatively, the data that had been compiled were elaborated descriptively. In every cycle, data were analyzed and reflected as the input for improvement in the next cycle. By the end of the research, all data were used to evaluate whether using infographic could improve students reading comprehension.

\section{Procedure (Cycle 1)}

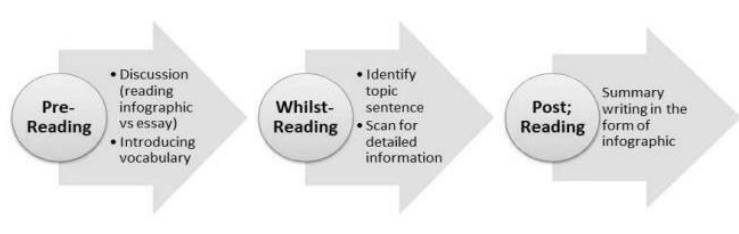

Procedure (Cycle 2)
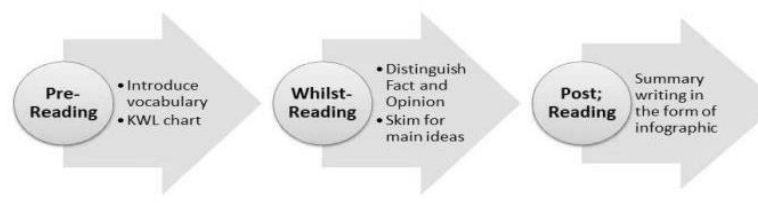

Figure 5. The Reading Activities of Cycle 1 and Cycle 2.

\section{FINDINGS AND DISCUSSION}

After conducting cycle 1, researchers found that discussion as pre-reading activities in cycle 1 helped learners understand what infographic is, although it turned out to be time consuming. That learners know Canva well had made the process of infographic making ran well. However, learners needed extra time to learn summary writing. Learners preferred 
Globish (An English-Indonesian journal for English, Education and Culture)

Vol. 9 No.2 July 2020

P-ISSN: 2301-9913, E-ISSN: 2597-9132

DOI: http://dx.doi.org/10.31000/globish.v7i2

smaller group work. Based from the reflection of this first cycle, researchers decided to conduct the second cycle.

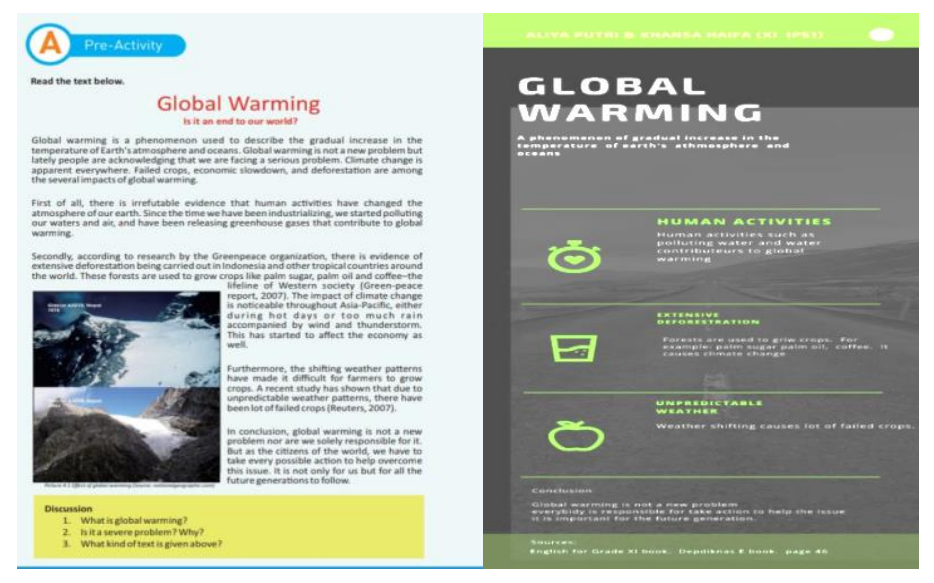

Figure 6. Summary of the Reading Text by using Infographics. Cycle 1.

Reflection of Cycle 2 showed that it is more effective to have students work in pairs. The process of infographic making facilitates 4 Cs (Critical Thinking, Creativity, Collaboration and Communication) in the classroom. Learners still need practice how to make sentences and phrases for infographics.

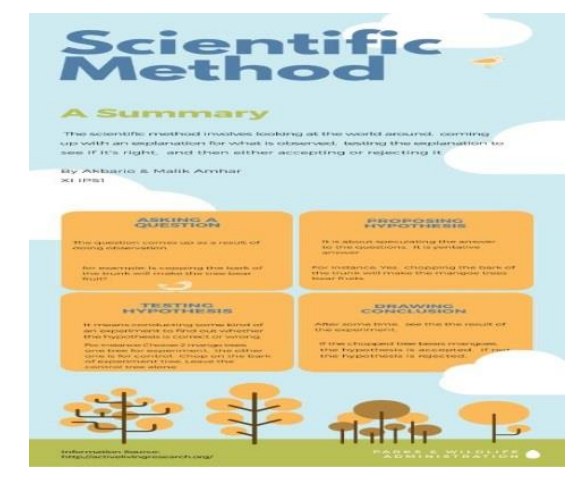

Figure 7. Summary of the Reading Text by using Infographics. Cycle 2.

During the pedagogical intervention, teacher asked students to work collaboratively in small groups. As the result, they could have a deeper understanding of the reading passage. According to Kongwat and Sukavatee (2019), by being while involved in collaborative reading instruction, students were encouraged to work together to solve problems they faced. While doing the task, students from different background knowledge levels could learn from each other, exchange information after reading the passages, defend their ideas, and co-construct meaning from the texts through the group discussion. Thus, collaborative reading instruction 
Globish (An English-Indonesian journal for English, Education and Culture)

Vol. 9 No.2 July 2020

P-ISSN: 2301-9913, E-ISSN: 2597-9132

DOI: http://dx.doi.org/10.31000/globish.v7i2

not only enhanced students' reading comprehension, but also engaged students more fully in the lesson.

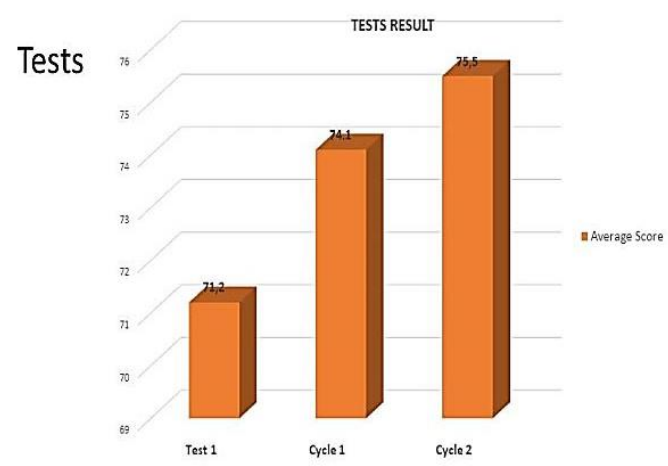

Figure 8. The results of Reading Comprehension Tests.

Figure 8 indicates that students' reading comprehension showed improvement (average score from pre test was 71.2; average score from cycle 1was 74.1 and average score from cycle 2 was 75.5). Students admitted that after using Infographic in cycle 1 and 2 of, they can write summary text better. The test results also showed students had improved their reading comprehension, as they have to conceptualize the main idea and the details of the text through the process of creating the infographics. This finding is congruent with the research conducted by Kongwat and Sukavatee (2019).

The results from the questionnaires showed that students gave positive responses toward the infographics tasks (table 1). Learners perceived the activities motivating as they could do something intriguing such as using application from their smartphones. They stated that Infographics facilitated them to think critically and work collaboratively. And they were also stimulate to be creative, as they have to design eye catchy infographic. These findings are congruent with a research conducted by Kongwat and Sukavatee (2019), they found out that infographics help students effectively improve their reading comprehension. The students could comprehend the reading text well as they were able to conceptualize the main idea and the details of the text through the process of creating the infographics. They also had analyzed the information and discussed it in a group to find the agreement about what should be presented in their work.

Table 1. Students Responses toward using infographic for summary writing 
Globish (An English-Indonesian journal for English, Education and Culture)

Vol. 9 No.2 July 2020

P-ISSN: 2301-9913, E-ISSN: 2597-9132

DOI: http://dx.doi.org/10.31000/globish.v7i2

\begin{tabular}{|l|c|c|c|c|}
\hline \multirow{2}{*}{ Statement } & \multicolumn{2}{|c|}{$\begin{array}{c}\text { Expected Responses } \\
\text { (Positive) }\end{array}$} & $\begin{array}{c}\text { Not expected Responses } \\
\text { (Negative) }\end{array}$ \\
\cline { 2 - 5 } & Totally Agree & Agree & $\begin{array}{l}\text { Somewhat } \\
\text { Agree }\end{array}$ & Disagree \\
\hline $\begin{array}{l}\text { The activities of making infographic are } \\
\text { interesting }\end{array}$ & 21 & 19 & - & - \\
\hline I practice how to write summary & 19 & 14 & 7 & - \\
\hline $\begin{array}{l}\text { Learning summary writing helps me } \\
\text { understand reading text better }\end{array}$ & 18 & 18 & 4 & - \\
\hline $\begin{array}{l}\text { I practice how to think critically, work } \\
\text { collaboratively during infographic making } \\
\text { process }\end{array}$ & 21 & 13 & 6 & \\
\hline The practice facilitates me to be creative & 23 & 12 & 5 & - \\
\hline
\end{tabular}

Moreover, various skills were developed through the creation of the infographics, such as information analysis, summarizing skills, higher thinking skills, creative thinking skills and collaborative learning.

\section{CONCLUSSION}

1. The implementation of infographics for summary writing can make the reading class more interesting

2. Learners perceived the activities can stimulate their critical thinking, creativity and collaborative skills.

3. Infographics could help learners to improve their reading comprehension and summary writing

4. Learners still need more practice on language accuracy.

5. There shall be more research conducted to investigate the effects of implementing infographics on summary writing, either qualitative or quantitative research.

\section{REFERENCES}

Anderson, Neil. (2003). Reading. In D Nunan (Ed.) Practical English Language Teaching. (1st ed., pp 67-86). New York: Mc Graw-Hill. 
Globish (An English-Indonesian journal for English, Education and Culture)

Vol. 9 No.2 July 2020

P-ISSN: 2301-9913, E-ISSN: 2597-9132

DOI: http://dx.doi.org/10.31000/globish.v7i2

Akkakoson, S. (2012). Raising Strategic Awareness Of Thai EFL Students Of Science And Technology Disciplines Through Metacognitive Strategy Training. 3L: The Southeast Asian Journal of English Language Studies, 18(4), 35-47.

Brown, H. D and Abeywickrama, P. (2010). Language Assessment: Principles and Classroom Practices. New York: Pearson-Longman.

Burns, Anne. (2010). Doing Action Research in English Language Teaching. New York: Routledge.

Fitrisia, Dohra, Kok-Eng Tan and Yunisrina QismullahYusuf. (2015). Investigating Metacognitive Awareness of Reading Strategies to Strengthen Students' Performance In Reading Comprehension. Asia Pacific Journal of Educators and Education,Vol.30, 1530 ,

Harmer, Jeremy. (2012). Teacher Knowledge: Core Concepts in English Teaching. Essex: Pearson.

Halvorsen, A. (2018). 21st Century Skills and the "4Cs" in the English Language Classroom. Retrieved from https://scholarsbank.uoregon.edu/xmlui/bitstream/handle/1794/23598/ halvorsen 21 century skills.pdf

Kongwat, A. and P. Sukavatee. (2019). The Effects of Collaborative Reading Instruction Using Infographics on Students' Reading Comprehension. Online Journal of Education, Vol. 14(2).

Lee, J.F and B. Van Patten. (2004). Make Communicative Language Teaching Happen. New York: Mc Graw - Hill.

Manowong, Supaporn. (2017). Incorporating Online Tools to Promote English Reading for EFL Learners: an Action Research Study. Pasaaparittat journal vol. 32,

Matrix, S and J. Hodson. (2014). Teaching with Infographics: Practicing New Digital Competencies and Visual Literacies. Retrieved https://www.beds.ac.uk/jpd/volume-4-issue-2/teaching-with-infographics

Mistar, Zuhairi, and Yanti(2016) Strategies Training in the Teaching of Reading Comprehension for EFL Learners in Indonesia. English Language Teaching, 9(2), 49-56

P21 Network. (2019). Framework for 21 st Century Learning. Retrieved from: http://static.battelleforkids.org/documents/p21/P21 Framework Brief.pdf

Santosa, M. H. (2017). Learning approaches of Indonesian EFL Gen Z students in a Flipped Learning context. Journal on English as a Foreign Language, 7 (2), 183-208.

Santosa, M.H. (2019). Introduction to Core Skills and Its Best Practices in the Indonesian Classroom. In: M.H. Santosa (Ed.). Penerapan Core Skills di Kelas-Kelas Indonesia. (pp. 723). Malang: Azizah Publishing.

Sparks \& Honey. (2014, June 17). Meet Gen Z: Forget everything you learned about Millennials. Retrieved from: www.sparksandhoney.com 
Globish (An English-Indonesian journal for English, Education and Culture)

Vol. 9 No.2 July 2020

P-ISSN: 2301-9913, E-ISSN: 2597-9132

DOI: http://dx.doi.org/10.31000/globish.v7i2

Suryanto. (2017). An Investigation On English Reading Comprehension Problems In Indonesian Cultural Contexts. The 1st International Conference on Education, Science, Art and Technology (ICESAT) Universitas Negeri Makassar. 22 - 23 July 2017 (pp 200-205)

Appendix 1. Reading Comprehension Test Results (Class XI IIS-1) 
Globish (An English-Indonesian journal for English, Education and Culture) Vol. 9 No.2 July 2020

P-ISSN: 2301-9913, E-ISSN: 2597-9132

DOI: http://dx.doi.org/10.31000/globish.v7i2

\begin{tabular}{|c|c|c|c|c|}
\hline Student & Male/Female & Test 1 & Test 2 & Test 3 \\
\hline 1 & M & 60,0 & 65,0 & 65,0 \\
\hline 2 & $\mathrm{~F}$ & 45,0 & 55,0 & 65,0 \\
\hline 3 & $M$ & 72.5 & 75,0 & 75,0 \\
\hline 4 & $\mathrm{M}$ & 80,0 & 80,0 & 80,0 \\
\hline 5 & $\mathrm{~F}$ & 77,5 & 80,0 & 80,0 \\
\hline 6 & $\mathrm{~F}$ & 70,0 & 72,5 & 75,0 \\
\hline 7 & $\mathrm{~F}$ & 50,0 & 60,0 & 70,0 \\
\hline 8 & $\mathrm{~F}$ & 70,0 & 75,0 & 75,0 \\
\hline 9 & $\mathrm{~F}$ & 60,0 & 65,0 & 65,0 \\
\hline 10 & $M$ & 67,5 & 75,0 & 75,0 \\
\hline 11 & $\mathrm{~F}$ & 60,0 & 70,0 & 70,0 \\
\hline 12 & $\mathrm{~F}$ & 60,0 & 65,0 & 70,0 \\
\hline 13 & $\mathrm{M}$ & 60,0 & 65,0 & 65,0 \\
\hline 14 & $M$ & 55,0 & 60,0 & 70,0 \\
\hline 15 & $\mathrm{~F}$ & 70,0 & 75,0 & 75,0 \\
\hline 16 & $\mathrm{~F}$ & 65,0 & 67,5 & 67,5 \\
\hline 17 & $\mathrm{~F}$ & 72,5 & 75,0 & 75,0 \\
\hline 18 & $M$ & 80,0 & 80,0 & 80,0 \\
\hline 19 & $\mathrm{~F}$ & 75,0 & 75,0 & 75,0 \\
\hline 20 & $\mathrm{~F}$ & 87,5 & 85,0 & 85,0 \\
\hline 21 & $\mathrm{~F}$ & 70,0 & 75,0 & 75,0 \\
\hline 22 & M & 65,0 & 70,0 & 70,0 \\
\hline 23 & $M$ & 80,0 & 80,0 & 80,0 \\
\hline 24 & M & 65,0 & 67,5 & 70,0 \\
\hline 25 & $\mathrm{~F}$ & 65,0 & 70,0 & 70,0 \\
\hline 26 & $\mathrm{~F}$ & 75,0 & 77,5 & 77,5 \\
\hline 27 & M & 67,5 & 70,0 & 75,0 \\
\hline 28 & $\mathrm{~F}$ & 77,5 & 75,0 & 75,0 \\
\hline 29 & $\mathrm{M}$ & 72,5 & 80,0 & 80,0 \\
\hline 30 & $M$ & 70,0 & 75,0 & 75,0 \\
\hline 31 & $\mathrm{M}$ & 77,5 & 75,0 & 75,0 \\
\hline 32 & $M$ & 75,0 & 80,0 & 80,0 \\
\hline 33 & $\mathrm{~F}$ & 85,0 & 82,5 & 82,5 \\
\hline 34 & $M$ & 80,0 & 85,0 & 85,0 \\
\hline 35 & $\mathrm{~F}$ & 85,0 & 82,5 & 82,5 \\
\hline 36 & $\mathrm{~F}$ & 75,0 & 80,0 & 80,0 \\
\hline 37 & $\mathrm{~F}$ & 80,0 & 77,5 & 82,5 \\
\hline 38 & $\mathrm{~F}$ & 80,0 & 82,5 & 80,0 \\
\hline 39 & $\mathrm{~F}$ & 85,0 & 80,0 & 80,0 \\
\hline 40 & $\mathrm{~F}$ & 80,0 & 80,0 & 87,5 \\
\hline \multicolumn{2}{|c|}{ AVERAGE } & 71,2 & 74,1 & 75,5 \\
\hline
\end{tabular}

